\title{
LC GENRE/FORM TERMS FOR RELIGIOUS MATERIAL PROJECT
}

A summary of terms proposed to date was circulated to Project roster members on Aug. 26, 2011. A copy (called "Working notes") was also posted to the "Genre Forms for Religious Terms Project" webpage at http://www.atla.com/Members/benefits/projects/Pages/GenreForms.aspx (no password required). Comments on that summary were due by Oct. 14, 2011. A first draft of proposed terms should be available for review by late autumn. Copies of that draft will be mailed to Project roster members. A copy will also be posted to the website and an announcement sent to altatech-l.

Submitted by Erica Treesh

Database Manager for Authority Control, ATLA Religion Database

American Theological Library Association

\section{TRAINING PRESENTATIONS, WEBCASTS, AND WEBINARS}

RDA Toolkit Webcast

RDA Checkpoint -- Where We Are and Where We're Heading

Presented by Troy Linker, Publisher for ALA Digital Reference, on July 12, 2011.

Slides and webinar

http://www.rdatoolkit.org/webinar/2011Jul

Georgia Cataloging Summit

This past summer the Georgia Public Library Service hosted the Georgia Cataloging Summit. Presenters included Dr. Barbara B. Tillett and Judith A. Kuhagen. The PowerPoint presentations for the Library of Congress RDA Workshop for Georgia Cataloging Summit are accessible on the Training Modules for RDA at the Library of Congress Resource Description and Access at the Library of Congress Webpage:

http://www.loc.gov/aba/rda/training modules.html

\section{ALCTS}

Aiming for a Robust Metadata Infrastructure for the Future

http://www.ala.org/ala/mgrps/divs/alcts/confevents/upcoming/webinar/cat/080111.cfm

Don't Tilt at Windmills, An Active Learning Approach to Teaching FRBR

http://www.ala.org/ala/mgrps/divs/alcts/confevents/upcoming/webinar/cat/120110.cfm 
FRBR as a Foundation for RDA

http://www.ala.org/ala/mgrps/divs/alcts/confevents/upcoming/webinar/cat/121510.cfm

ALCTS also offers several other webinars and webcasts. Many of the presentations are free. For more information go to the ALCTS Webinar Archives:

http://www.ala.org/ala/mgrps/divs/alcts/confevents/past/webinar/index.cfm

Minitex

FRBR and FRAD: Keys to RDA November 16 and 18, December 19 and 21

http://www.minitex.umn.edu/Training/Details.aspx?SessionID=350

RDA for the Solo/Copy Cataloger Webinar Series, December 8 and 15

http://www.minitex.umn.edu/Training/Details.aspx?SessionID=351

Lyrasis

Born Digital Cataloging Items on the Web (Live Online), November 17, 2011 and April 5, 2012

http://www.lyrasis.org/?sc itemid= \{CDBB338D-D015-4457-B93D-

6E88F5FC28DC $; \&$ RowId=1-N6TF5

Copy Cataloging a Serial Live Online December 7-8, 2011 and April 21-22, 2012

http://www.lyrasis.org/?sc itemid $=\{$ F8954BED-1CFE-4727-A0D8-

4021D796A059 $\&$ \&owId=1-MK9Z7

Introduction to Audio-Visual Cataloging (Live Online) November 29, 2011 and January 25, 2011

http://www.lyrasis.org/?sc itemid $=\{$ A2CAD0F0-C8BB-46F8-AB96-

$\underline{132581601 \mathrm{C} 86\} \& \text { RowId=1-LW5V6 }}$

FRBR, FRAD, FRSAD: A New Model for Cataloging, January 10, 2012, (http://www.lyrasis.org/?sc itemid= \{DDD1FDFC-617D-4C72-9BF4-

B29619BAE12A $\&$ \&owId=1-GXPME)

\section{SELECTED ARTICLES FROM CURRENT LIBRARY JOURNALS}

Beall, Jeffrey. “Abbreviations, Full Spellings, and Searchers' Preferences.” Cataloging \& Classification Quarterly 49, no. 6 (2011): 443-456. 